\title{
Regulation of Mammary and Adipose Tissue Lipoprotein Lipase and Blood Triacylglycerol in Rats during Late Pregnancy
}

\author{
EFFECT OF PROSTAGLANDINS \\ Peter M. Spooner, Mary M. Garrison, and Robert O. Scow \\ From the Section on Endocrinology, Laboratory of Nutrition and Endocrinology, National \\ Institute of Arthritis, Metabolism, and Digestive Diseases, National \\ Institutes of Health, Bethesda, Maryland 20014
}

\begin{abstract}
A B S T RACT The effects of several prostaglandins on lipoprotein lipase activity of mammary gland and adipose tissue and serum triacylglycerol were studied during late pregnancy in rats. Prostaglandins were injected twice daily for 2 days before and once on the day of analysis. In rats pregnant 20 days, prostaglandin $\mathrm{F}_{2 \alpha}\left(\mathrm{PGF}_{2 \alpha}\right)$ increased the activity of lipoprotein lipase in mammary gland fourfold, reduced the activity in adipose tissue about $60 \%$, and decreased serum concentration of triacylglycerol $50 \%$. $\mathrm{PGF}_{2 \alpha}$ also reduced serum concentration of progesterone $90 \%$ and increased that of prolactin fivefold, but had no effect on serum concentrations of either immunoreactive insulin or $17 \beta$-estradiol. Injections of 13,14 dihydro-15-keto $\mathrm{PGF}_{2 \alpha}$, a metabolite of $\mathrm{PGF}_{2 \alpha}$, had similar effects in rats pregnant 20 days, whereas prostaglandins $E_{1}$ and $E_{2}$ did not. In rats pregnant 16 days, $\mathrm{PGF}_{2 \alpha}$ did not affect lipoprotein lipase activity in the tissues or the concentration of triacylglycerol and prolactin in serum, although it decreased serum progesterone $80 \%$.

2 -Br- $\alpha$-ergocryptine prevented the increase in serum prolactin in response to $\mathrm{PGF}_{2 \alpha}$, but did not alter the effects of $\mathrm{PGF}_{2 \alpha}$ on lipoprotein lipase activity or serum triacylglycerol. Progesterone completely blocked the effects of $\mathrm{PGF}_{2 \alpha}$ on lipoprotein lipase activity and serum triacylglycerol and prolactin concentrations.
\end{abstract}

\footnotetext{
A preliminary account of this work was presented at the 1976 Annual Meeting of the Endocrine Society, San Francisco, Calif., and appeared in 1976. Endocrinology. 98: 183A. (Abstr.)

Received for publication 24 January 1977 and in revised form 10 May 1977.
}

These findings indicate that the changes in lipoprotein lipase activity and serum triacylglycerol in $\mathrm{PGF}_{2 \alpha}$-treated rats are probably related to the inhibitory action of $\mathrm{PGF}_{2 \alpha}$ on progesterone secretion. They also suggest that endogenous $F$ prostaglandins may play a role in the regulation of lipoprotein lipase activity in mammary gland and adipose tissue near parturition.

\section{INTRODUCTION}

Lipoprotein lipase, acting in capillary endothelium, regulates the uptake of triacylglycerol from chylomicrons and very low density lipoproteins by mammary, adipose, and other extrahepatic tissues (1-3). Lipoprotein lipase activity of mammary gland increases in pregnant animals 2-3 days before parturition and remains high throughout lactation (4). Lipoprotein lipase activity of adipose tissue decreases before parturition, and remains low throughout lactation $(4,5)$. These changes in lipolytic activity in late pregnant rats are accompanied by a marked decrease in blood triacylglycerol concentration, and serve during lactation to divert blood triacylglycerol fatty acids from storage in adipose tissue to milk production in mammary gland (5). ${ }^{1}$ Studies in hypophysectomized lactating rats showed that the changes which occur in lipoprotein lipase activity in late pregnancy are maintained during lactation by the action of prolactin, secreted from the anterior pituitary gland (6).

\footnotetext{
${ }^{1}$ Scow, R. O., S. S. Chernick, and T. R. Fleck. 1976. Lipoprotein lipase and uptake of triacylglycerol, cholesterol, and phosphatidylcholine from chylomicrons by mammary and adipose tissue of lactating rats in vivo. Submitted for publication.
} 
There is little information concerning factors that regulate lipoprotein lipase activity in mammary and adipose tissue during late pregnancy. During this period, there are alterations in blood concentrations of several hormones-prolactin, insulin, estrogen, and progesterone-which can affect lipolytic activity in these tissues (7-9). Release of endogenous $F$ prostaglandins from the uterus is markedly increased at about the time (2-3 days prepartum) that the initial changes in lipoprotein lipase activity of mammary and adipose tissue occur (10). Administration of prostaglandin $F_{2 \alpha}\left(P_{2 \alpha}\right)^{2}$ during late pregnancy initiates parturition and advances the onset of lactation in both rodents and humans (11-13). Previously, Strauss and Stambaugh (14) suggested that $\mathrm{PGF}_{2 \alpha}$ may alter the activity of lipoprotein lipase in the rat corpus luteum near term.

The present studies were undertaken to evaluate the effects of several prostaglandins and prolactin on lipoprotein lipase activity in mammary and adipose tissue and on serum triacylglycerol concentration in rats during late pregnancy. The effects of $\mathrm{PGF}_{2 \alpha}$ on serum concentrations of prolactin, insulin, estrogen, and progesterone were also determined.

\section{METHODS}

Animals. Primiparous Sprague-Dawley rats were obtained from Charles River Breeding Laboratories (Wilmington, Mass.), and allowed free access to water and Purina National Institutes of Health Open Formula Rat and Mouse Ration \#5018 (Ralston Purina Co., St. Louis, Mo.). Day 1 of pregnancy was designated as the day on which, after overnight mating, spermatozoa were found in the vaginal smear. Animals were injected during two different stages of pregnancy. Analyses on day 16 of pregnancy were made in animals injected at 08:30 and 17:00 $\mathrm{h}$ on days 14 and 15 , and again at $08: 30$ on day 16. Analyses on day 20 of pregnancy were made in animals injected at 08:30 and 17:00 h on days 18 and 19, and again at $08: 30$ on the morning of day 20. Animals were decapitated 3-4 h after the last injection, and trunk blood was collected for analyses of serum components. Rats carrying less than six fetuses at autopsy, and those delivering prematurely, were excluded from the study.

Agents injected. All injections were given intramuscularly (i.m.) using $<0.25 \mathrm{ml}$ of appropriate carrier solution. Control animals were injected with diluent carrier solution alone. $\mathrm{PGF}_{2 \alpha}$ tromethamine salt was dissolved in $0.15 \mathrm{M}$ $\mathrm{NaCl}$ solution. Prostaglandin $\mathrm{E}_{1}\left(\mathrm{PGE}_{1}\right)$, prostaglandin $\mathrm{E}_{2}$ $\left(\mathrm{PGE}_{2}\right)$, and 13,14-dihydro-15-keto prostaglandin $\mathrm{F}_{2 \alpha}$ (DHK$\mathrm{PGF}_{2 \alpha}$ ) were dissolved in $10 \%$ ethanol-0.2 $\mathrm{M}$ phosphate solution, $\mathrm{pH}$ 6.5. Prostaglandins were generously supplied by Dr. John Pike of the Upjohn Co., Kalamazoo, Mich. Bovine prolactin (National Institutes of Health-P-B3), donated by the Pituitary Hormone Distribution Program, National

${ }^{2}$ Abbreviations used in this paper: DHK-PGF $2 \alpha, 13,14-\mathrm{di}-$ hydro-15-keto prostaglandin $\mathrm{F}_{2 \alpha}$; NIAMDD, National Institute of Arthritis, Metabolism and Digestive Diseases; $\mathrm{PGE}_{1}$, prostaglandin $\mathrm{E}_{1} ; \mathrm{PGE}_{2}$, prostaglandin $\mathrm{E}_{2} ; \mathrm{PGF}_{2 \alpha}$, prostaglandin $\mathrm{F}_{2 \alpha}$.
Institute of Arthritis, Metabolism and Digestive Diseases (NIAMDD; Bethesda, Md.), was dissolved in $0.1 \mathrm{M} \mathrm{NaHCO}_{3}$ solution, $\mathrm{pH}$ 8.1. 2-Br- $\alpha$-ergocryptine (Compound CB-154), a gift from Sandoz Pharmaceuticals (East Hanover, N. J.), was dissolved in warm $20 \%$ ethanol- $0.15 \mathrm{M} \mathrm{NaCl}$ solution. Progesterone (in sesame oil) was purchased from Eli Lily and Company (Indianapolis, Ind.).

Preparation of activated triacylglycerol particles. The substrate used for assay of lipoprotein lipase activity was prepared as follows: $100 \mu \mathrm{mol}$ of trioleoylglycerol (lot Z-IT, Hormel Institute, Austin, Minn.); 25-63 $\mu \mathrm{Ci}$ of tri- $\left.{ }^{14} \mathrm{C}\right]$ oleoylglycerol $(55 \mathrm{mCi} / \mathrm{mmol}$, Amersham/Searle Corp., Arlington Heights, Ill.) or tri- $\left[{ }^{3} \mathrm{H}\right]$ oleoylglycerol $(521 \mathrm{mCi} /$ $\mathrm{mmol}$, Amersham/Searle); $175 \mu \mathrm{l}$ of $4.3 \%$ Triton X-100 (Sigma Chemical Co., St. Louis, Mo.), in water; $3.13 \mathrm{ml}$ of fasted rat serum and $4.3 \mathrm{ml} 20 \%$ crystallized bovine serum albumin (lot no. N-72905, Armour Pharmaceutical Company, Phoenix, Ariz.) in $0.3 \mathrm{M}$ Tris- $\mathrm{HCl}$ solution, $\mathrm{pH} 8.1$, were combined and sonicated for 3 min (45-s bursts with intermittent cooling) with a Bronwill Biosonik III (Bronwill Scientific, Rochester, N.Y.) at $50 \%$ maximal output. The mixture was then centrifuged at $60,000 \mathrm{~g}$ for $90 \mathrm{~min}$ at $4^{\circ} \mathrm{C}$ with the Beckman 50.1 rotor (Beckman Instruments, Inc., Fullerton, Calif.). The resulting floating layer of activated triacylglycerol particles was resuspended in $2.5 \mathrm{ml}$ of $4 \%$ bovine serum albumin in water and briefly sonicated. Electron microscope examination of the suspension, stained with sodium phosphotungstate, kindly performed by Dr. E. Joan Blanchette-Mackie of NIAMDD demonstrated that the particles had a diameter of $1,500 \pm 900 \AA( \pm S D)$.

Lipoprotein lipase determination. Segments of inguinalabdominal mammary gland, $67 \mathrm{mg} / \mathrm{ml}$, and parametrial adipose tissue, $100 \mathrm{mg} / \mathrm{ml}$, were homogenized in $25 \mathrm{mM}$ $\mathrm{NH}_{3}-\mathrm{NH}_{4} \mathrm{Cl}$ buffer, $\mathrm{pH} 8.1$, containing $4 \mathrm{U}$ of heparin $/ \mathrm{ml}$ (Eli Lily) at $4^{\circ} \mathrm{C}$ with a Tekmar Tissumizer (Tekmar Co., Cincinnati, Ohio). Homogenates were centrifuged at $2,000 \mathrm{~g}$ for $20 \mathrm{~min}$ at $4^{\circ} \mathrm{C}$, and the clear supernatant fraction was removed and stored at $4^{\circ} \mathrm{C}$ for assay within $60 \mathrm{~min}$. Preliminary experiments established that lipoprotein lipase activity in the extracts (supernatant fraction from above) was stable for at least $2 \mathrm{~h}$. The extracts contained at most 0.15 $\mu \mathrm{mol}$ of esterified fatty acids/100 $\mu \mathrm{l}(15)$.

Lipoprotein lipase activity in tissue extracts was measured by the amount of fatty acids formed from serum-activated triacylglycerol. Each extract was assayed in duplicate. Each assay contained in a final volume of $500 \mu \mathrm{l}: 50-100 \mu \mathrm{l}$ of tissue extract, $4 \mu \mathrm{mol}$ of activated triacylglycerol, $0.63 \mu \mathrm{mol}$ of crystallized bovine serum albumin, $0.5 \mathrm{U}$ of heparin, $5 \mu \mathrm{mol} \mathrm{NH}_{4} \mathrm{Cl}$, and $62 \mu \mathrm{mol}$ Tris- $\mathrm{HCl}, \mathrm{pH}$ 8.1. The assay mixture was incubated at $37^{\circ} \mathrm{C}$ for $30-60 \mathrm{~min}$ in a shaking water bath. After incubation, lipids were extracted into hexane by a modification of the procedure of Dole (16), using hexane instead of heptane. Fatty acids in the hexane extract were partitioned into $0.05 \mathrm{M} \mathrm{NaOH}-50 \%$ ethanol solution (17). Radioactivity in the hexane and $\mathrm{NaOH}$-ethanol extracts was quantified with Aquasol scintillant (New England Nuclear, Boston, Mass.), in a Nuclear Chicago Mark II Scintillation Spectrometer (Nuclear-Chicago Corp., Des Plains, Ill.).

Lipolytic activities, based on tissue wet weights, were calculated from the amount of radioactive oleic acid formed during incubation. The rate of production was linear with respect to time (up to $60 \mathrm{~min}$ ), and the amount of tissue extract added (up to $3 \mathrm{mg}$ of mammary gland protein and 0.3 $\mathrm{mg}$ of adipose tissue protein added per assay [18]). The rate was unaffected by increasing the amount of substrate added. Lipolytic activity in extracts of mammary glands of control and $\mathrm{PGF}_{2 \alpha}$-treated 20-day pregnant rats was inhibited $>90 \%$ when the assay mixture contained $1 \mathrm{M} \mathrm{NaCl}$, or when 
unactivated trioleoylglycerol particles, prepared in the absence of serum, were used. $1 \mathrm{U}$ of lipase activity is defined as the release of $1 \mu \mathrm{mol}$ of fatty acid/min. Because of interassay variation in absolute lipase activity, control and experimental groups were assayed in a paired manner in each experiment. Comparison of absolute activity levels are thus valid only within this context.

Serum analyses. Serum was prepared from blood by centrifugation at $2,000 \mathrm{~g}$ for $20 \mathrm{~min}$ at $4^{\circ} \mathrm{C}$ and stored in liquid $\mathbf{N}_{2}$. Triacylglycerol in serum was measured by the "2-vial" method and reagents supplied by Calbiochem, Inc. (San Diego, Calif.). Prolactin was measured by doubleantibody radioimmunoassay with methods and materials provided by the NIAMDD Rat Pituitary Hormone Program. Rat prolactin was iodinated (sp act-75-90 $\mu \mathrm{Ci} / \mathrm{ng}$ ) with ${ }^{125} \mathrm{I}-\mathrm{Na}$ (11-17 mCi/ng I, Amersham/Searle) by the chloramine-T procedure recommended. After addition of $25 \mathrm{mg}$ carrier bovine serum albumin (Armour), monomeric ${ }^{125} \mathrm{I}$ prolactin was isolated by chromatography on a $90 \times 1.5-\mathrm{cm}$ column of Sephadex G-100 (Pharmacia Fine Chemicals, Piscataway, N. J.; 19). The second antibody employed, goat antirabbit gamma globulin, was purchased from Calbiochem. Assays were performed in triplicate and the data analyzed by the "Logit-Log" method of Rodbard et al. (20). Progesterone (21) and $17 \beta$-estradiol (22) radioimmunoassays were performed by Hazelton Laboratories (Vienna, Va.). PGF levels were determined by the method of Shemesh and Hansel (23) with plasma samples obtained by cardiac puncture. Recoveries of added tracer $\left[{ }^{3} \mathrm{H}\right] \mathrm{PGF}_{2 \alpha}(178 \mathrm{Ci} / \mathrm{mmol}$, New England Nuclear) averaged $55 \pm 8 \%$. The antibody employed (Upjohn Co.) cross-reacted $\sim 50 \%$ with $\mathrm{PGF}_{1 \alpha}$, but $<0.1 \%$ with DHK-PGF $_{2 \alpha}, \mathrm{E}, \mathrm{B}$, or $\mathrm{A}$ type prostaglandins. Immunoreactive insulin was kindly determined by Carla Hendricks, Diabetes Branch, NIAMDD, Bethesda, Md., by a heterologous radioimmunoassay $(24)$.

\section{RESULTS}

Effects of PGF ${ }_{2 \alpha}$. The effect of $\mathrm{PGF}_{2 \alpha}$ on lipoprotein lipase activity in mammary gland and adipose tissue, and on serum concentrations of triacylglycerol and hormones was studied in rats pregnant for 16 and 20 days. The rats were injected i.m. with $250 \mu \mathrm{g}$ of $\mathrm{PGF}_{2 \alpha}$ tromethamine salt twice daily for 2 days before and once on the day of analysis.
Lipoprotein lipase activity in mammary gland and adipose tissue did not change significantly in control rats between the 16th and 20th days of pregnancy, whereas the serum concentration of triacylglycerol increased almost twofold and that of progesterone decreased from 86 to $51 \mathrm{ng} / \mathrm{ml}$ (Table I). In 16-day pregnant rats $\mathrm{PGF}_{2 \alpha}$ had no effect on lipoprotein lipase activity in either tissue or on serum triacylglycerol concentration, whereas it reduced serum progesterone concentration from 86 to $16 \mathrm{ng} / \mathrm{ml}$. In 20-day pregnant rats, however, $\mathrm{PGF}_{2 \alpha}$ increased lipoprotein lipase activity in mammary gland by threefold and decreased the activity in adipose tissue $60 \%$. Serum concentrations of triacylglycerol declined $50 \%$ and progesterone levels fell from 51 to $4 \mathrm{ng} / \mathrm{ml}$. $\mathrm{PGF}_{2 \alpha}$ had no effect in either group on body weight gain during the injection period.

The effect of $\mathrm{PGF}_{2 \alpha}$ on serum concentrations of several hormones which may alter lipoprotein lipase activity in mammary and adipose tissues was determined in another series of experiments (Table II). $\mathrm{PGF}_{2 \alpha}$ increased serum prolactin concentration by fivefold in 20-day pregnant rats, but had no effect on serum prolactin in 16-day pregnant rats or on serum insulin and $17 \beta$-estradiol concentrations in either group. Mammary gland weight and milk formation were also determined in these experiments as an index of lactational development. Mammary gland weight gain and formation of milk were observed only in the 20-day pregnant rats treated with $\mathrm{PGF}_{2 \alpha}$ (Table II).

Peripheral plasma PGF concentrations were determined $3 \mathrm{~h}$ after the last iniection of $\mathrm{PGF}_{2 \alpha}$ in a separate group of 16- and 20-day pregnant animals. PGF levels in the 16-day group $(n=5)$ were all below assay detection limits $\left(\sim 0.23 \mathrm{ng} \mathrm{PGF}_{2 \alpha} / \mathrm{ml}\right.$ blood). PGF levels in the 20-day pregnant group $(n=5)$ averaged $0.31 \mathrm{ng} / \mathrm{ml}$ in two animals but were undetectable in the remaining three animals.

TABLE I

Effects of PGF P $_{2 \alpha}$ on Lipoprotein Lipase Activity of Mammary Gland and Adipose Tissue, and Serum Concentration of Triacylglycerol and Progesterone in Pregnant Rats

\begin{tabular}{|c|c|c|c|c|c|c|}
\hline \multirow{2}{*}{$\begin{array}{c}\text { Days } \\
\text { pregnant }\end{array}$} & \multirow[b]{2}{*}{ Group } & \multirow{2}{*}{$\begin{array}{l}\text { No. of } \\
\text { animals }\end{array}$} & \multicolumn{2}{|c|}{ Lipoprotein lipase activity } & \multicolumn{2}{|c|}{ Serum concentration } \\
\hline & & & Mammary gland & Adipose tissue & Triacylglycerol & Progesterone \\
\hline & & & \multicolumn{2}{|c|}{$\mathrm{mU} / \mathrm{g}$} & $m M$ & $n g / m l$ \\
\hline 16 & Control & 6 & $323 \pm 35$ & $505 \pm 72$ & $1.44 \pm 0.22$ & $86 \pm 7$ \\
\hline 16 & $\mathrm{PGF}_{2 \alpha}$ & 6 & $251 \pm 24$ & $510 \pm 156$ & $1.10 \pm 0.20$ & $16 \pm 3^{*}$ \\
\hline 20 & Control & 9 & $265 \pm 36$ & $836 \pm 184$ & $2.71 \pm 0.31$ & $51 \pm 3$ \\
\hline 20 & $\mathrm{PGF}_{2 \alpha}$ & 9 & $791 \pm 105^{*}$ & $320 \pm 51 *$ & $1.36 \pm 0.14^{*}$ & $4 \pm 1^{*}$ \\
\hline
\end{tabular}

Treated rats were given $250 \mu \mathrm{g}$ of $\mathrm{PGF}_{2 \alpha}$ tromethamine salt i.m. twice daily for 2 days before and once on the day of analysis. Values given are means \pm SE. In this and all subsequent tables $1 \mathrm{mU}$ of lipase activity represents the release of $1 \mathrm{nmol}$ of fatty acid/min.

* Significantly different from values for control group by Student's $t$ test for unpaired data $(P<0.01)$. 
TABLE II

Effect of PGF $F_{2 \alpha}$ on Serum Concentration of Prolactin, Insulin, and Estradiol, Weight of Mammary Glands, and Milk Formation in Pregnant Rats

\begin{tabular}{|c|c|c|c|c|c|c|c|}
\hline \multirow{2}{*}{$\begin{array}{c}\text { Days } \\
\text { pregnant }\end{array}$} & \multirow[b]{2}{*}{ Group } & \multirow{2}{*}{$\begin{array}{l}\text { No. of } \\
\text { animals }\end{array}$} & \multicolumn{3}{|c|}{ Serum concentration } & \multirow{2}{*}{$\begin{array}{c}\text { Weight of } \\
\text { inguinal-abdominal } \\
\text { mammary glands }\end{array}$} & \multirow{2}{*}{$\begin{array}{l}\text { Index of } \\
\text { milk } \\
\text { formation }\end{array}$} \\
\hline & & & Prolactin & Insulin & $17 \beta$-estradiol & & \\
\hline & & & $n g / m l$ & $\mu(1 / m l$ & $\mathrm{pg} / \mathrm{ml}$ & $g$ & \\
\hline 16 & Control & 8 & $34 \pm 3$ & $39 \pm 5$ & $58 \pm 12$ & $2.3 \pm 0.2$ & 0 \\
\hline 16 & $\mathrm{PGF}_{2 \alpha}$ & 8 & $34 \pm 3$ & $49 \pm 5$ & $89 \pm 10$ & $2.6 \pm 0.1$ & 0 \\
\hline 20 & Control & 11 & $40 \pm 6$ & $59 \pm 8$ & $63 \pm 8$ & $3.2 \pm 0.2$ & 0 \\
\hline 20 & $\mathrm{PGF}_{2 \alpha}$ & 11 & $243 \pm 35^{*}$ & $44 \pm 5$ & $65 \pm 7$ & $4.8 \pm 0.2^{*}$ & $100^{*}$ \\
\hline
\end{tabular}

Treated rats were given $250 \mu \mathrm{g}$ of $\mathrm{PGF}_{2 \alpha}$ tromethamine salt i.m. twice daily for 2 days before and once on the day of analysis. Prolactin, insulin, and $17 \beta$-estradiol were determined by radioimmunoassay. Prolactin values are referenced to the NIAMDD rat prolactin-rat pituitary-l standard. Insulin values are expressed in terms of a Novo Al70 rat insulin standard. Index of milk formation indicates percent of animals in which mammary tissue contained white lucid fluid at autopsy. Values given are means $\pm \mathrm{SE}$.

* Significantly different from values for control group by Student's $t$ test for unpaired data $(P<0.001)$.

Effect of other prostaglandins. The effects of DHK-PGF $F_{2 \alpha}$, a major metabolite of $\mathrm{PGF}_{2 \alpha}$, and of $\mathrm{PGE}_{1}$ and $\mathrm{PGE}_{2}$ were compared with those of $\mathrm{PGF}_{2 \alpha}$ in 20-day pregnant rats (Table III). The metabolite DHK-PGF $F_{2 \alpha}$ increased lipoprotein lipase activity in mammary gland, decreased the activity in adipose tissue, increased serum prolactin, and decreased serum triacylglycerol and progesterone concentrations to levels comparable to those obtained in rats treated with $\mathrm{PGF}_{2 \alpha}$. $\mathrm{PGE}_{1}$ and $\mathrm{PGE}_{2}$ both decreased serum progesterone concentrations more than $50 \%$, but had no effect on lipoprotein lipase activity in either tissue or on serum prolactin. $\mathrm{PGE}_{1}$, but not $\mathrm{PGE}_{2}$, also reduced the concentration of triacylglycerol in serum. The changes in lipoprotein lipase activities in rats treated with $\mathrm{PGF}_{2 \alpha}$ or its metabolite were associated with a $90 \%$ decrease of progesterone and a four- to sixfold increase in serum prolactin concentration.

Effect of prolactin. Injection of exogenous (bovine) prolactin for 2 days had no effect on lipoprotein lipase activity in mammary and adipose tissues or on serum concentrations of triacylglycerol and progesterone in either 16- or 20-day pregnant rats (Table IV).

Effect of exogenous progesterone and 2-Br- $\alpha$-ergocryptine on the response to $P G F_{2 \alpha}$. To examine the relation between the effects of $\mathrm{PGF}_{2 \alpha}$ on serum progesterone and prolactin concentrations, and its effect on lipoprotein lipase activity in tissues, 20-day pregnant rats were injected with $\mathrm{PGF}_{2 \alpha}$ in combination with either progesterone or 2-Br- $\alpha$-ergocryptine, a synthetic alkaloid inhibitor of pituitary prolactin

TABLE III

Effect of Different Prostaglandins on Lipoprotein Lipase Activity of Mammary Gland and Adipose Tissue, and Serum Concentrations of Triacylglycerol, Progesterone, and Prolactin in Rats Pregnant for 20 Days

\begin{tabular}{|c|c|c|c|c|c|c|c|}
\hline \multirow[b]{2}{*}{ Group } & \multirow{2}{*}{$\begin{array}{l}\text { No. of } \\
\text { animals }\end{array}$} & \multicolumn{3}{|c|}{ Lipoprotein lipase activity } & \multicolumn{3}{|c|}{ Serum concentration } \\
\hline & & Mammary gland & Adipose tissue & $\mathbf{M} / \mathrm{A}^{*}$ & Triacylglycerol & Progesterone & Prolactin \\
\hline & & & $m U / g$ & & $m M$ & $n g / m l$ & $n g / m l$ \\
\hline Control & 6 & $348 \pm 37$ & $543 \pm 69$ & 0.6 & $3.58 \pm 0.41$ & $64 \pm 7$ & $64 \pm 12$ \\
\hline $\mathrm{PGF}_{2 \alpha}$ & 4 & $2,336 \pm 602 \ddagger$ & $311 \pm 81+$ & $7.5 \ddagger$ & $1.11 \pm 0.17 \ddagger$ & $4 \pm 1 \ddagger$ & $297 \pm 40 \ddagger$ \\
\hline $\mathrm{DHK}_{-\mathrm{PGF}} \mathrm{F}_{2 \alpha}$ & 4 & $1,126 \pm 260 \ddagger$ & $151 \pm 29 \ddagger$ & $7.5 \ddagger$ & $1.54 \pm 0.37 \ddagger$ & $6 \pm 2 \ddagger$ & $400 \pm 96$ \\
\hline $\mathrm{PGE}_{1}$ & 3 & $282 \pm 55$ & $455 \pm 104$ & 0.6 & $1.62 \pm 0.17 \ddagger$ & $26 \pm 3 \ddagger$ & $59 \pm 9$ \\
\hline $\mathrm{PGE}_{2}$ & 3 & $456 \pm 52$ & $689 \pm 236$ & 0.7 & $2.89 \pm 0.97$ & $21 \pm 2 \ddagger$ & $42 \pm 19$ \\
\hline
\end{tabular}

Treated rats were given $250 \mu \mathrm{g}$ of prostaglandin i.m. twice daily for 2 days before and once on the day of analysis.

* M/A expresses the ratio of lipolytic activity in mammary gland to that in adipose tissue. Values given are means \pm SE.

† Significantly different from values for control group by Student's $t$ test for unpaired data $(P<0.05)$. 
I ABLE IV

Effect of Prolactin on Lipoprotein Lipase Activity of Mammary Gland and Adipose Tissue, Serum Concentration of Triacylglycerol and Progesterone, and Weight of Mammary Glands in Pregnant Rats

\begin{tabular}{|c|c|c|c|c|c|c|c|}
\hline \multirow{2}{*}{$\begin{array}{c}\text { Days } \\
\text { pregnant }\end{array}$} & \multirow[b]{2}{*}{ Group } & \multirow{2}{*}{$\begin{array}{l}\text { No. of } \\
\text { animals }\end{array}$} & \multicolumn{2}{|c|}{ Lipoprotein lipase activity } & \multicolumn{2}{|c|}{ Serum concentration } & \multirow{2}{*}{$\begin{array}{l}\text { Weight of inguinal- } \\
\text { abdominal mammary } \\
\text { glands (unilateral) }\end{array}$} \\
\hline & & & Mammary gland & Adipose tissue & Triacylglycerol & Progesterone & \\
\hline & & & \multicolumn{2}{|c|}{$m U / g$} & $m \cdot M$ & $n g / m l$ & $g$ \\
\hline 16 & Control & 6 & $440 \pm 98$ & $650 \pm 210$ & $1.14 \pm 0.22$ & - & $2.0 \pm 0.1$ \\
\hline 16 & Prolactin & 6 & $581 \pm 93$ & $685 \pm 76$ & $1.50 \pm 0.27$ & - & $1.8 \pm 0.1$ \\
\hline 20 & Control & 6 & $457 \pm 53$ & $851 \pm 129$ & $2.93 \pm 0.32$ & $64 \pm 6$ & $3.1 \pm 0.1$ \\
\hline 20 & Prolactin & 6 & $514 \pm 71$ & $901 \pm 206$ & $2.50 \pm 0.43$ & $59 \pm 5$ & $3.5 \pm 0.3$ \\
\hline
\end{tabular}

Treated rats were given $1.5 \mathrm{mg}$ of bovine (National Institutes of Health-P-B3) prolactin i.m. twice daily for 2 days before and once on the day of analysis. Values given are means $\pm \mathrm{SE}$.

release (25). Administration of progesterone completely blocked the effect of $\mathrm{PGF}_{2 \alpha}$ on lipoprotein lipase activity in both tissues and on serum prolactin concentration, as well as on weight gain and milk formation in mammary gland (Table V). Although 2 - $\mathrm{Br}$ - $\alpha$-ergocryptine blocked the expected increase in serum prolactin in response to $\mathrm{PGF}_{2 \alpha}$, it did not alter the other effects of $\mathrm{PGF}_{2 \alpha}$.

\section{DISCUSSION}

Lipoprotein lipase activity increases markedly in mammary gland and decreases, more than $60 \%$, in adipose tissue of pregnant rats several days before parturition. These changes in enzyme activity are accompanied by a reduction in serum triacylglycerol and persist during lactation as long as suckling is continued (4). Zinder et al. (6) found that in lactating rats, hypophysectomy greatly reduced lipoprotein lipase activity in mammary gland and increased the activity in adipose tissue. Injections of bovine prolactin for $48 \mathrm{~h}$ restored the activity in each tissuc to levels characteristic of the lactating state (6). They concluded that prolactin plays a major role in maintaining the activity of the enzyme in lactating mammary tissue. Changes in lipoprotein lipase activity in mammary gland of lactating rats (4) closely parallel changes in circulating prolactin levels during periods of suckling and nonsuckling (26). Because serum prolactin levels increase greatly 2-3 days before parturition $(26,27$, it seemed possible that the alterations in lipoprotein lipase activity in mammary and adipose tissues which occur during late pregnancy might be due to prolactin.

Injections of $\mathrm{PGF}_{2 \alpha}$ in rats pregnant 20 days increased lipoprotein lipase activity in mammary gland four- to sixfold, reduced the activity in adipose tissue $60 \%$, and decreased serum triacylglycerol concentration 50\%. $\mathrm{PGF}_{2 \alpha}$ also increased serum prolactin four- to fivefold and decreased serum progesterone concentration more than $90 \%$ (Tables I and II). These findings suggested that the increase in serum prolactin might be part of the mechanism whereby $\mathrm{PGF}_{2 \alpha}$ altered

TABLE V

Effect of Progesterone and 2-Br- $\alpha$-Ergocryptine on the Response to $P G F_{2 \alpha}$ in Rats Pregnant for 20 Days

\begin{tabular}{|c|c|c|c|c|c|c|c|c|}
\hline \multirow[b]{2}{*}{ Group } & \multirow[b]{2}{*}{$\begin{array}{l}\text { No. of } \\
\text { animals }\end{array}$} & \multicolumn{2}{|c|}{ Lipoprotein lipase activity } & \multicolumn{3}{|c|}{ Serum concentration } & \multirow{2}{*}{$\begin{array}{l}\text { Weight of } \\
\text { inguinal- } \\
\text { abdominal } \\
\text { mammary } \\
\text { glands } \\
\text { (unilateral }\end{array}$} & \multirow{2}{*}{$\begin{array}{c}\text { Index } \\
\text { of milk } \\
\text { forma- } \\
\text { tion }\end{array}$} \\
\hline & & $\begin{array}{c}\text { Mammary } \\
\text { gland }\end{array}$ & $\begin{array}{l}\text { Adipose } \\
\text { tissue }\end{array}$ & $\begin{array}{l}\text { Triacyl- } \\
\text { glycerol }\end{array}$ & $\begin{array}{l}\text { Proges- } \\
\text { terone }\end{array}$ & Prolactin & & \\
\hline & & \multicolumn{2}{|c|}{$m C^{1} / g$} & $m .11$ & $n g / m l$ & $n g / m l$ & $g$ & \\
\hline \multirow{4}{*}{$\begin{array}{l}\text { Control } \\
\text { PGF }_{2 \alpha} \\
\mathrm{PGF}_{2 \alpha}+\text { pro- } \\
\text { gesterone } \\
\mathrm{PGF}_{2 \alpha}+2-\mathrm{Br}-\alpha- \\
\text { ergocryptine }\end{array}$} & 5 & $778 \pm 164$ & $1,602 \pm 528$ & $2.61 \pm 0.42$ & $69 \pm 7$ & $72 \pm 16$ & $3.6 \pm 0.3$ & 0 \\
\hline & 6 & $2,035 \pm 358^{*}$ & $5.53 \pm 76^{*}$ & $1.14 \pm 0.15^{*}$ & $4 \pm 1^{*}$ & $248 \pm 43^{*}$ & $5.1 \pm 0.1 *$ & $100^{*}$ \\
\hline & 6 & $614 \pm 93$ & $1,045 \pm 196$ & $2.55 \pm 0.25$ & $209 \pm 24^{*}$ & $59 \pm 12$ & $3.4 \pm 0.3$ & 0 \\
\hline & 6 & $1,449 \pm 292 *$ & $303 \pm 33^{*}$ & $1.46 \pm 0.26^{*}$ & $9 \pm 2 *$ & $39 \pm 7 *$ & $5.8 \pm 0.5^{*}$ & $100^{*}$ \\
\hline
\end{tabular}

Treated rats were given $250 \mu \mathrm{g}$ of $\mathrm{PGF}_{2 \alpha}$ tromethamine salt with or without $5 \mathrm{mg}$ of progesterone or $0.5 \mathrm{mg}$ of $2-\mathrm{Br}-\alpha-$ ergocryptine i.m. twice daily for 2 days before and once on the day of analysis. Values given are means \pm SE.

* Significantly different from values for control group by Student's $t$ test for unpaired data $(P<0.05)$. 
tissue levels of lipoprotein lipase activity. However, injections of prolactin alone had no effect on lipoprotein lipase activity in animals pregnant 16 or 20 days (Table IV), indicating that the response to $\mathrm{PGF}_{2 \alpha}$ is not mediated simply by increased serum prolactin levels. This inference is supported by the results obtained when 2-Br- $\alpha$-ergocryptine was injected with $\mathrm{PGF}_{2 \alpha}$ (Table V): 2-Br- $\alpha$-ergocryptine completely inhibited the effect of $\mathrm{PGF}_{2 \alpha}$ on serum prolactin levels, but did not alter the effects on lipoprotein lipase activity or serum triacylglycerol.

Vermouth and Deis $(12,28)$ jreviously observed that $\mathrm{PGF}_{2 \alpha}$ increased serum prolactin in rats pregnant 17-19 days and postulated that this was an effect secondary to decreased serum levels of progesterone. Our findings show an inverse correlation between the effects of $\mathrm{PGF}_{2 \alpha}$ on serum progesterone and prolactin levels on the 20th, but not on the 16th day of pregnancy (Tables I-III). Others (29) have recently reported increased production of prolactin by pituitary cells incubated with $\mathrm{PGF}_{2 \alpha}$ in vitro, suggesting that prostaglandins may have direct effects on pituitary hormone secretion.

The effects of $\mathrm{PGF}_{2 \alpha}$ on serum concentrations of immunoreactive insulin and $17 \beta$-estradiol were determined because of the possibility that alterations in the levels of these hormones might affect the activity of lipoprotein lipase. Insulin stimulates lipoprotein lipase activity in adipose tissue of normal, diabetic, and obese animals, and lowered blood levels of this hormone are associated with decreased enzyme activity in the tissue $(9,30,31)$. In rats, insulin levels which are elevated in mid-pregnancy decline just before term (32). Other studies on nonpregnant rats have shown that administration of estrogen decreases the activity of lipoprotein lipase in adipose tissue $(7,8)$ and increases its activity in mammary gland (8). Estrogen levels in pregnant rats increase markedly just before parturition (10). The present work (Table II) shows that PGF $_{2 \alpha}$ had no effect on serum insulin or $17 \beta$-estradiol concentrations in 20-day pregnant rats, although lipoprotein lipase activity in adipose tissue decreased more than $60 \%$, whereas that in mammary gland increased threefold.

The effects of $\mathrm{PGF}_{2 \alpha}$ on tissue lipoprotein lipase activities in 20-day pregnant rats were associated with a $90 \%$ decrease in the circulating concentration of progesterone (Table I). Injection of progesterone with $\mathrm{PGF}_{2 \alpha}$ blocked all effects of prostaglandin in 20-day pregnant rats (Table V). These results indicate that the suppression of progesterone secretion by $\mathrm{PGF}_{2 \alpha}$ may be a central event in mediating the effects on lipoprotein lipase activities and on serum triacylglycerol. The failure of $\mathrm{PGF}_{2 \alpha}$ to elicit these responses in rats 16 days pregnant could be the result of an insufficient reduction of progesterone levels at this stage of pregnancy (Table I). Alternatively, it may indicate that alterations in other components of the hormonal milieu, such as placental lactogen, which is low on day 16 and high on day 20 of pregnancy (33), are also involved.

The effects of $\mathrm{PGF}_{2 \alpha}$ on serum concentrations of progesterone observed here agree well with results of earlier studies (see references 11 and 34 for recent reviews). $\mathrm{PGF}_{2 \alpha}$ reduces progesterone production by the corpus luteum of pregnancy in a number of species. This effect has been ascribed to both direct effects of $\mathrm{PGF}_{2 \alpha}$ on the ovarian vasculature (35) and more recently to increased activity of a luteal $20-\alpha$-steroid dehydrogenase which metabolizes progesterone to the inactive progestin, 20- $\alpha$-OH-pregn-4-ene-3-one (36). The partial inhibitory effects of $\mathrm{PGE}_{1}$ and $\mathrm{PGE}_{2}$ on serum progesterone levels (Table III) have also been observed previously (35). The failure of $\mathrm{PGE}_{1}$ and $\mathrm{PGE}_{2}$ to alter significantly lipoprotein lipase activity in mammary and adipose tissues (Table III) may be a reflection of their inability to deplete serum progesterone levels to the same extent as $\mathrm{PGF}_{2 \alpha}$. DHK-PGF ${ }_{2 \alpha}$, a major circulating metabolite of $\mathrm{PGF}_{2 \alpha}$, produced effects similar to those of $\mathrm{PGF}_{2 \alpha}$ on tissue lipoprotein lipase activities and serum concentrations of triacylglycerol and hormones (Table III). This finding was unexpected because prostaglandin metabolites such as the 13,14-dihydro-15 keto derivatives have usually been regarded as relatively inactive $(37,38)$. Our results (Table III) suggest that prostaglandin metabolites, such as DHK-PGF ${ }_{2 \alpha}$, may have a greater physiological relevance than generally assumed.

Serum progesterone levels in rats increase during pregnancy and remain high until several days before parturition (27). Stimulation of milk protein and carbohydrate synthesis by lactogenic and supportive hormones (insulin, estrogens, and corticosteroids) have been shown to require the prior withdrawal of progesterone (39-41). The results of the present work show that the reduction in serum progesterone levels induced by $\mathrm{PGF}_{2 \alpha}$ in late (i.e. 20-day) pregnant rats is associated with alterations in lipoprotein lipase activities which facilitate uptake of blood triacylglycerol by mammary gland for incorporation into milk lipids. $\mathrm{PGF}_{2 \alpha}$ administration thus not only advances the day of pregnancy on which parturition occurs but also results in hormonal and enzymatic changes which stimulate milk production. These considerations suggest that the release of $\mathrm{F}$ prostaglandins from the uterus just before parturition $(10,11,37)$ may be a significant physiological signal in the initiation of lactation.

\section{ACKNOWLEDGMENTS}

We wish to thank Dr. Jerry Strauss for helpful discussions during the initiation of the work. Doctors Bruce Weintraub, Harry Keiser, and Beth Stannard provided valuable advice on radioimmunoassay procedures. Dr. Sidney Chernick provided valuable help throughout. 


\section{REFERENCES}

1. Scow, R. O., C. R. Mendelson, O. Zinder, M. Hamosh, and E. J. Blanchette-Mackie. 1973. Role of lipoprotein lipase in the delivery of dietary fatty acids to lactating mammary tissue. In Dietary Lipids and Postnatal Development. C. Galli, G. Jacini and A. Pecile, editors. Raven Press, New York. 91-114.

2. Scow, R. O., E. J. Blanchette-Mackie, and L. C. Smith. 1976. Role of capillary endothelium in the clearance of chylomicrons. Circ. Res. 39: 149- 162.

3. Robinson, D. S. 1970. The function of the plasma triglyceride in fatty acid transport. In Comprehensive Biochemistry. M. Florkin, and E. H. Stotz, editors. Elsevier Publishing Co., New York. 18: 51-116.

4. Hamosh, M., T. R. Clary, S. S. Chernick, and R. O. Scow. 1970. Lipoprotein lipase activity of adipose and mammary tissue and plasma triglyceride in pregnant and lactating rats. Biochim. Biophys. Acta. 210: 473-482.

5. Otway, S., and D. S. Robinson. 1968. The significance of changes in tissue clearing-factor lipase activity in relation to the lipemia of pregnancy. Biochem. J.106: $677-682$.

6. Zinder, O., M. Hamosh, T. R. C. Fleck, and R. O. Scow. 1974. Effect of prolactin on lipoprotein lipase in mammary gland and adipose tissue of rats. Am. J. Physiol. 226: 744-748.

7. Hamosh, M., and P. Hamosh. 1975. The effect of estrogen on the lipoprotein lipase activity of rat adipose tissue. J. Clin. Invest. 55: 1132-1135.

8. Kim, H-J., and R. K. Kalkhoff. 1975. Sex steroid influence on triglyceride metabolism. J. Clin. Invest. 56: 888-896.

9. Borensztajn, J., D. R. Samols, and A. H. Rubenstein. 1972. Effects of insulin on lipoprotein lipase activity in the rat heart and adipose tissue. Am. J. Physiol. 223: 1271-1275.

10. Labhsetwar, A. P., and D. J. Watson. 1974. Temporal relationship between secretory patterns of gonadotropins, estrogens, progestins, and prostaglandin- $\mathrm{F}$ in periparturient rats. Biol. Reprod. 10: 103-110.

11. Labhsetwar, A. P. 1974. Prostaglandins and the reproductive cycle. Fed. Proc. 33: 61-77.

12. Vermouth, N. J., and R. P. Deis. 1972. Prolactin release induced by prostaglandin $\mathrm{F}_{2 \alpha}$ in pregnant rats. Nat. New Biol. 238: 248-250.

13. Smith, I. D., R. P. Shearman, and A. R. Korda. 1972. Lactation following therapeutic abortion with prostaglandin $\mathrm{F}_{2 \alpha}$. Nature (Lond.). 240: 411-412.

14. Strauss, J. F., and R. L. Stambaugh. 1975. Luteal triacylglycerol storage during luteolysis. Fed. Proc. 34: 324.

15. Rapport, M. M., and N. Alonzo. 1959. Photometric determination of fatty acid ester groups in phospholipids. J. Biol. Chem. 217: 193-198.

16. Dole, V. P. 1956. A relation between non-esterified fatty acids in plasma and the metabolism of glucose. J. Clin. Invest. 35: 150-154.

17. Borgstrom, B. 1952. Investigation on lipid separation methods: separation of cholesterol esters, glycerides and free fatty acids. Acta Physiol. Scand. 25: 111-119.

18. Lowry, O. H., N. J. Rosebrough, A. L. Farr, and R. J. Randall. 1951. Protein measurement with the Folin phenol reagent. J. Biol. Chem. 193: 265-275.

19. Kieffer, J. D., B. D. Weintraub, W. Baigelman, S. Leeman, and F. Maloof. 1974. Homologous radioimmunoassay of thyrotropin in rat plasma. Acta Endocrinol. 76: 495-505.

20. Rodbard, D., and G. R. Frazier. 1975. Statistical analysis of radioligand assay data. Methods Enzymol. 37: 3-22.

21. Abraham, G. E., R Swerdloff, D. Tulchinsky, and W. D.
Odell. 1971. Radioimmunoassay of plasma progesterone. J. Clin. Endocrinol. Metab. 32: 619-624.

22. Loriaux, D. L., H. J. Ruder, and M. B. Lipsett. 1971. The measurement of estrone sulfate in plasma. Steroids. 18: 463-472.

23. Shemesh, M., and W. Hansel. 1975. Levels of prostaglandin $F$ (PGF) in bovine endometrium, uterine venous, ovarian arterial and jugular plasma during the estrous cycle. Proc. Soc. Exp. Biol. Med. 148: 123-126.

24. Gordon, P., and C. M. Hendricks. 1974. The measurement of plasma insulin and proinsulin like components. In New Techniques in Tumor Localization and Radioimmunoassay. M. N. Croll, L. W. Brady, T. Honda, and R. J. Wallner, editors. John Wiley \& Sons, Inc., New York. 17-24.

25. Döhler, K. D., and W. Wuttke. 1974. Total blockade of phasic pituitary prolactin release in rats: effect on serum $\mathrm{LH}$ and progesterone during the estrous cycle and pregnancy. Endocrinology. 94: 1595-1600.

26. Amenomori, Y., C. L. Chen, and J. Meites. 1970. Serum prolactin levels in rats during different reproductive states. Endocrinology. 86: 506-510.

27. Morishige, W. K., G. J. Pepe, and I. Rothchild. 1973. Serum luteinizing hormone, prolactin and progesterone levels during pregnancy in the rat. Endocrinology. 92: $1527-1531$.

28. Vermouth, N. J., and R. P. Deis. 1975. Inhibitory effect of progesterone on the lactogenic and abortive action of prostaglandin $\mathrm{F}_{2 \alpha}$. J. Endocrinol. 66: 21-29.

29. Gautvik, K. M., and M. Kriz. 1976. Effects of prostaglandins on prolactin and growth hormone synthesis and secretion in cultured rat pituitary cells. Endocrinology. 98: 352-358.

30. Pykälisto, O. J., P. H. Smith, and J. D. Brunzell. 1975. Determinants of human adipose tissue lipoprotein lipase. J. Clin. Invest. 56: 1108-1117.

31. Enser, M. 1972. Clearing-factor lipase in obese hyperglycaemic mice (ob/ob). Biochem. J. 129: 447-453.

32. Knopp, R. H., C. D. Saudek, R. A. Arky, and J. B. O'Sullivan. 1973. Two phases of adipose tissue metabolism in pregnancy: maternal adaptations for fetal growth. Endocrinology. 92: 984-988.

33. Kelly, P. A., R. P. C. Shiu, M. C. Robertson, and H, G. Friesen. 1975. Characterization of rat chorionic mammotropin. Endocrinology. 96: 1187-1195.

34. Goldberg, V. J., and P. W. Ramwell. 1975, Role of prostaglandins in reproduction. Physiol. Rev. 55: 325-351.

35. Pharriss, B. 1971. Prostaglandin induction of luteolysis. Ann. N.Y. Acad. Sci. 180: 436-444.

36. Strauss, J. F., and R. L. Stambaugh, 1974, Induction of 20- $\alpha$-hydroxysteroid dehydrogenase in rat corpora lutea of pregnancy by prostaglandin $\mathrm{F}_{2 \alpha}$. Prostaglandins. 5: 73-85.

37. Samuelsson, B., E. Granström, K. Green, M. Hamberg, and S. Hammarström. 1975. Prostaglandins. Annu. Rev. Biochem. 44: 669-695.

38. Samuelsson, B., E. Granström, K. Green, and $M$. Hamberg. 1971. Metabolism of prostaglandins. Ann. N.Y. Acad. Sci. 180: 138-163.

39. Cowie, A. T., and J. S. Tindall. 1971. The Physiology of Lactation. Arnold Ltd., London, 392 pp.

40. Davis, W., J. Wikman-Coffelt, and C. L. Eddington. 1972 , The effect of progesterone on biosynthetic pathways in mammary tissue. Endocrinology, 91; 1011-1019.

41. Murphy, G., A. D. Ariyanayagam, and N. J. Kuhn. 1973. Progesterone and the metabolic control of the lactose biosynthetic pathway during lactogenesis in the rat. Biochem.J. 136: 1105-1116. 